\title{
Implementasi Database Auditing dengan Memanfaatkan Sinkronisasi DBMS
}

\author{
I Gede Anantaswarya Abhisena ${ }^{1}$, I Made Sukarsa ${ }^{2}$, Dwi Putra Githa ${ }^{3}$ \\ Program Studi Teknologi Informasi, Fakultas Teknik Universitas Udayana \\ Bukit Jimbaran, Bali \\ 1anantaswaryaas@hotmail.com \\ ${ }^{2}$ e_arsa@ymail.com \\ 3dwiputragitha@unud.ac.id
}

\begin{abstract}
Abstrak
Database auditing dapat menjadi komponen penting dalam keamanan basis data dan kepatuhan terhadap peraturan pemerintah. Database Administrator perlu lebih waspada dalam teknik yang digunakan untuk melindungi data perusahaan, serta memantau dan memastikan bahwa perlindungan yang memadai terhadap data tersedia. Pada tingkat tinggi, database auditing merupakan fasilitas untuk melacak otoritas dan penggunaan sumber daya database. Ketika fungsi auditing diaktifkan, setiap operasi database yang diaudit menghasilkan jejak audit dari perubahan informasi yang dilakukan. Sinkronisasi database adalah bentuk dari replikasi, yang merupakan proses untuk memastikan setiap salinan data pada database berisi objek dan data yang serupa. Sinkronisasi database dapat dimanfaatkan dalam berbagai keperluan, salah satunya membangun auditing untuk mencatat setiap aktivitas yang terjadi pada database. Jejak audit dari operasi database yang dihasilkan, memungkinkan DBA (Database Administrator) memelihara audit trails dari waktu ke waktu, untuk melakukan analisis tentang pola akses dan modifikasi terhadap data pada DBMS (Database Management System).
\end{abstract}

Kata kunci: Database Auditing, Jejak Audit, Keamanan Basis Data, Sinkronisasi Data

\begin{abstract}
Database auditing can be an important component in database security and governance regulations. Database Administrator needs to be more alert in the methods used to maintain the corporate data, and standards and requirements available against available data. At high level, databases auditing are facility to search the usage of database authority and resources. When auditing is active, every database operation that audited generates an audit trails of the information changes made. Database synchronization is a form of replication, which is a process to convincing every copy of database comprise the same data. Database synchronization allows to utilized many purposes, one of which builds auditing that records every activities occur at database. The audit trails from the resulting of data operations allows DBAs (Database Administrators) maintained audit trails time to time, to perform an analysis of access patterns and modifications to data in DBMS (Database Management System).
\end{abstract}

Keywords : Database Auditing, Audit Trail, Database Security, Data Synchronization

\section{Pendahuluan}

Kebutuhan perusahaan dalam melakukan analisis serta pembuatan laporan secara efektif, efisien dan terintegrasi dari sistem informasi menjadi penting untuk dikembangkan [1]. Banyak perusahaan menginginkan proses analisis dilakukan dengan waktu se-minimum mungkin [2]. Sistem Informasi telah didefinisikan dan diadopsi ke dalam praktik sejak awal revolusi digital. Sementara informasi telah digunakan untuk proses bisnis, keamanan informasi muncul dalam hal otentikasi dan otorisasi. Konsep tersebut dapat melindungi informasi namun tidak memberikan bantuan dalam penyelidikan. Log file diusulkan untuk melacak jejak akses ke database dan sistem. Namun, tujuan utama log file adalah untuk pemulihan (recovery) 
transaksi. Untuk dapat menginvestigasi transaksi yang terjadi, maka database auditing dapat menjadi pilihan [3]. Melakukan audit perubahan data pada database sangat penting untuk mengidentifikasi perilaku jahat, menjaga kualitas data, dan meningkatkan kinerja sistem [4].

Database auditing merupakan salah satu masalah utama dalam keamanan informasi. Kurangnya data auditing membawa aplikasi bisnis pada hilangnya jejak proses bisnis perusahaan. Untuk membangun auditing, data historis atau temporal database diperlukan untuk melacak operasi dan tipe operasi dengan waktu [3]. Database auditing dapat menjadi komponen penting dalam keamanan basis data dan kepatuhan terhadap peraturan pemerintah. Database Administrator perlu lebih waspada dalam teknik yang digunakan untuk melindungi data perusahaan, serta memantau dan memastikan bahwa perlindungan yang memadai terhadap data tersedia [5].

Sinkronisasi database adalah bagian dari replikasi, yang merupakan proses untuk memastikan setiap salinan data pada database berisi objek dan data yang serupa. Fungsi sinkronisasi yang berjalan pada suatu database mengakibatkan data diperbaharui secara real-time atau periodik setiap terjadinya perubahan data [6]. Kondisi ini dapat dimanfaatkan untuk membangun auditing yang mencatat setiap aktivitas yang terjadi pada database bersangkutan.

Kajian terhadap database auditing telah dilakukan oleh beberapa penelitian sebelumnya. Beberapa diantaranya memuat teori-teori dalam mendukung proses auditing. Penelitian dengan judul Database Auditing Design on Historical Data [3] mengusulkan beberapa metode untuk melakukan manajemen historikal data auditing pada database, seperti audit berbasis baris, audit berbasis kolom, audit dengan tabel log dan audit berbasis semi-struktur. Tiga teknik auditing pertama dapat diterapkan dengan database relasional, sedangkan audit berbasis semistruktur diterapkan dengan menggunakan extension dari mesin database relasional dan teknologi XML (extensions markup language) seperti IBM DB2 9.5, Oracle 10g, dan MS SQL Server. Penelitian dengan judul Teaching Database Security and Auditing [7] mengungkapkan banyak jejak audit (audit trails) yang dihasilkan untuk lingkungan database, sehingga terdapat beberapa kategori dalam auditing. Kategori audit pertama yang dibutuhkan pada kebanyakan lingkungan auditing adalah jejak audit dari log on dan log off, serta mencatat semua upaya log in yang gagal. Kategori kedua adalah auditing terhadap DCL (Data Control Language) pada database. DCL mencakup perubahan pada hak akses user, user login, dan atribut keamanan lainnya. Kategori ketiga adalah auditing terhadap DDL (Data Definition Language) seperti mengubah skema database atau tabel. Beberapa aktivitas pencurian informasi mungkin sering melibatkan perintah DDL. Kategori keempat adalah auditing terhadap perubahan data melalui aktivitas DML (Data Manipulation Language). Melalui auditing pada perintah DML, perubahan yang terjadi, baik nilai lama maupun nilai baru, dapat terekam. Kategori kelima adalah auditing perubahan terhadap sumber dari stored procedure dan trigger, dimana kode program untuk kejahatan dapat dengan mudah disembunyikan. Kategori keenam adalah auditing terhadap kesalahan database akibat berbagai hal, seperti penyerangan database oleh pihak tertentu.

Penelitian ini menerapkan teknik berbasis baris (row-based auditing) dalam implementasi database auditing untuk melakukan audit terhadap aktivitas DML pada transaksi bisnis dengan mempertimbangkan status operasi, waktu yang valid, dan tipe operasi menggunakan model relasional.

\section{Metodologi Penelitian}

Penelitian Implementasi Database Auditing Dengan Memanfaatkan Sinkronisasi DBMS ini mengunakan metode pengembangan sistem Waterfall yang terdapat didalam SDLC (Software Development Life Cycle). Pengembangan sistem dengan metode Waterfall menjadikan tahap pengembangan menjadi terstruktur. Tahapan analisa penelitian dari Implementasi Database Auditing Dengan Memanfaatkan Sinkronisasi DBMS adalah sebagai berikut :

1. Pendefinisian masalah dari sistem yang dirancang.

2. Pengumpulan data terkait perancangan sistem.

3. Pengumpulan dan penguasaan terkait teori pendukung untuk perancangan sistem.

4. Perancangan database menggunakan platform MySQL.

5. Perancangan engine sinkronisasi menggunakan bahasa pemrograman Python.

6. Pengujian sistem untuk memperoleh hasil yang sesuai.

7. Pengambilan kesimpulan. 


\subsection{Gambaran Umum Sinkronisasi}

Desain sinkronisasi diimplementasikan dalam proses pertukaran data pada DBMS MySQL ditunjukkan pada Gambar 1.

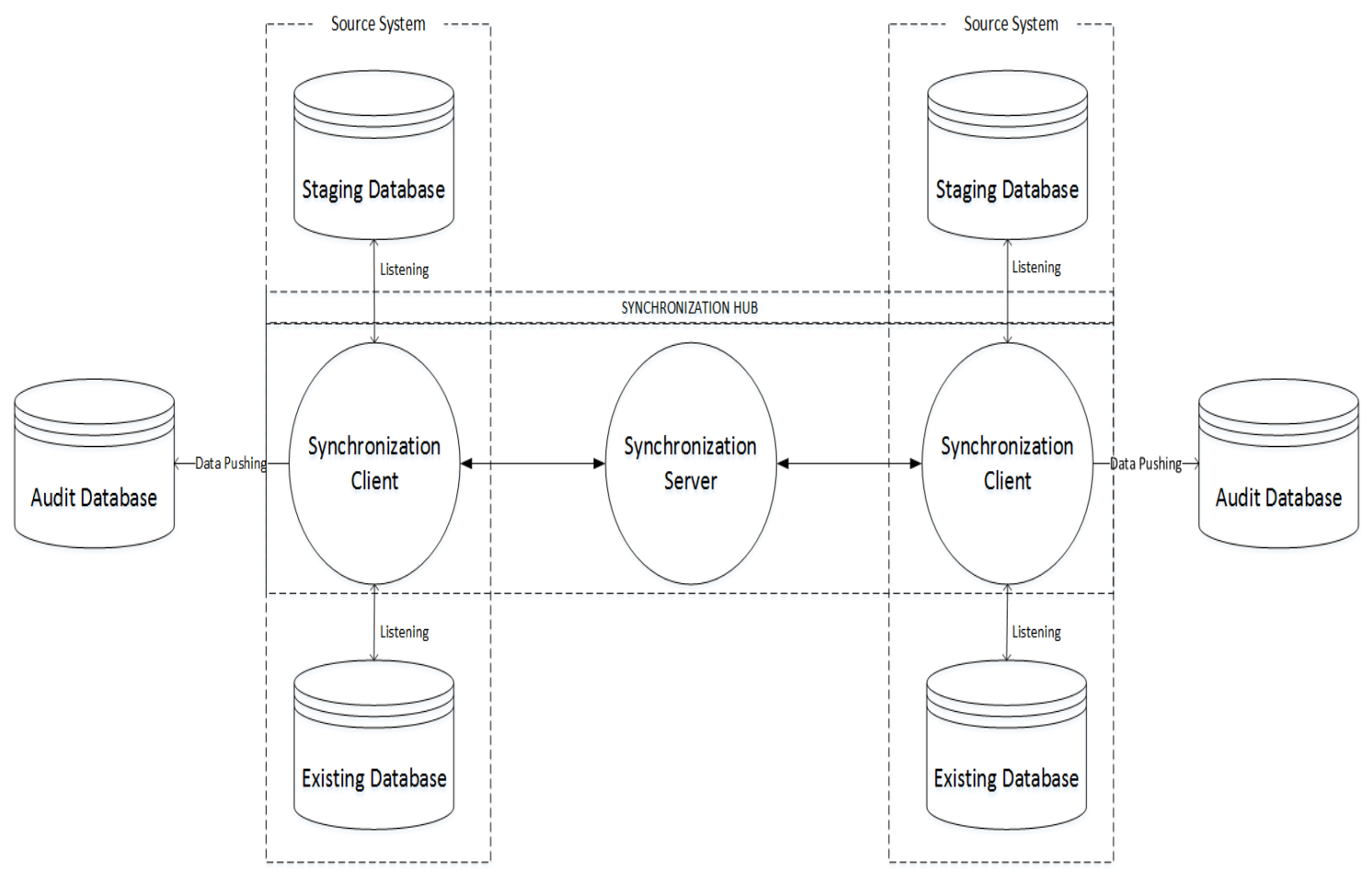

Gambar 1. Skema Arsitektur Sinkronisasi

Skema arsitektur dari engine sinkronisasi yang dirancang bersifat real-time. Setiap terdapat data baru atau terjadinya perubahan data pada database eksisting, maka perubahan data tersebut dikirim ke tempat tujuan, tersimpan sebagai row baru pada tabel auditing yang bersesuaian terhadap transaksi yang telah dilakukan.

Sebelum proses sinkronisasi, database yang disinkronkan pada sistem sumber antara database eksisting dan staging di setiap lokasi harus serupa. Hal ini dilakukan untuk memastikan data yang disinkronkan tetap konsisten. Jika kondisi ini sudah terpenuhi, maka proses sinkronisasi bisa dimulai.

Sinkronisasi yang terjadi pada database eksisting dan database staging mengakibatkan proses auditing menjadi lebih cepat karena database staging menempel pada database eksisting. Proses auditing dilakukan pada sistem sumber, sehingga auditing database hanya akan menerima hasil perubahan data yang terjadi.

\subsection{Proses Auditing}

Pada penelitian ini, proses auditing dihasilkan dari engine sinkronisasi yang bekerja secara terus menerus pada sistem sumber. Engine mulai bekerja ketika terjadi manipulation event pada database eksisting, yaitu ketika user memasukkan data baru, mengubah atau menghapus data atau beberapa field pada database eksisting. 


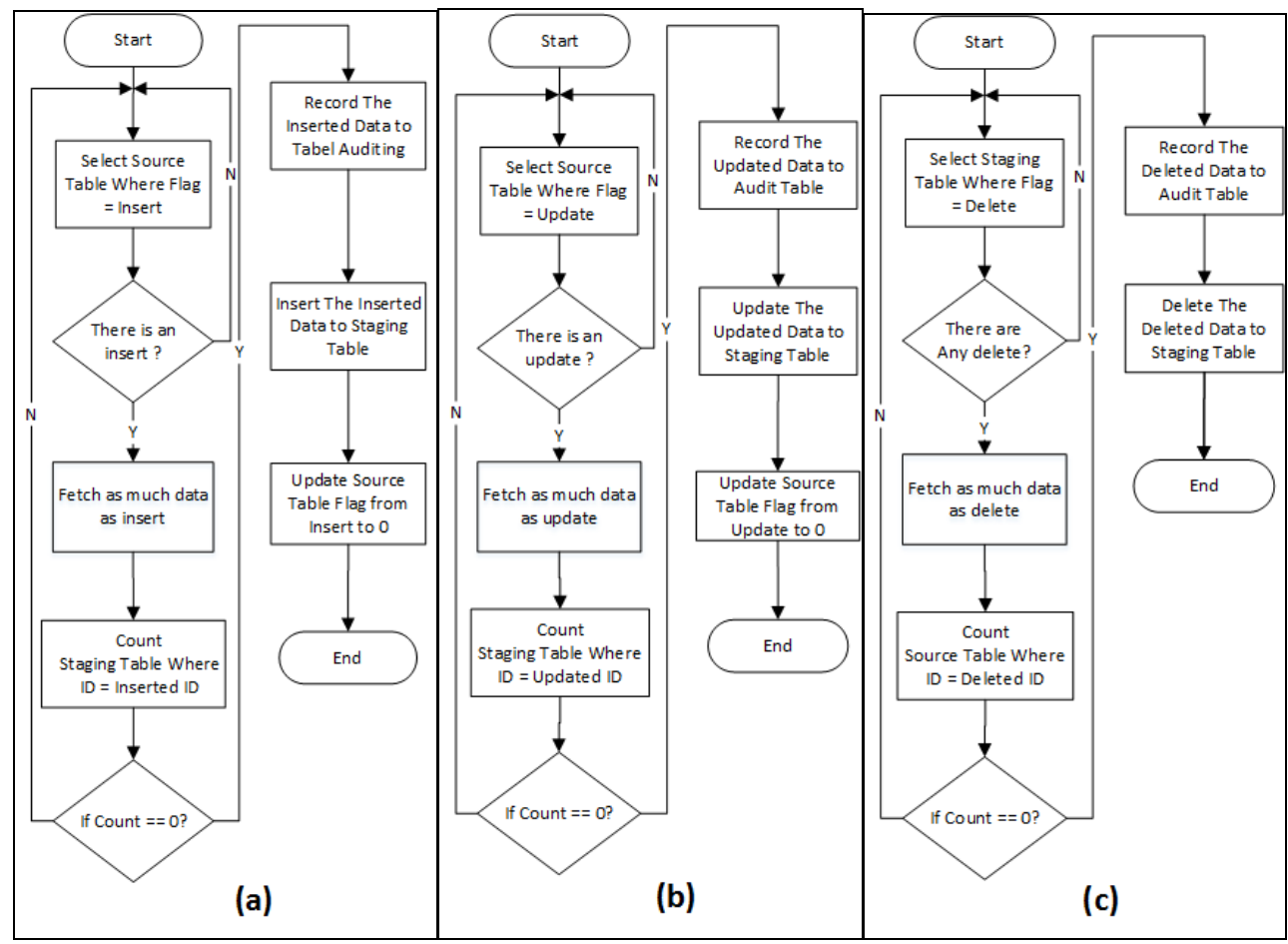

Gambar 2. Alur Auditing (a) Insert, (b) Update, (c) Delete

Engine akan bekerja saat terjadi insert event, menangkap data yang telah ter-insert dan kemudian menyimpannya sebagai record baru didalam tabel auditing yang sesuai pada database auditing. Update event untuk satu atau beberapa field, membuat engine menangkap perubahan yang dibuat dan menyimpannya sebagai record baru didalam tabel auditing yang sesuai pada database auditing. Begitu juga dengan delete event, engine sinkronisasi akan menangkap data yang terhapus dan menyimpannya sebagai record baru pada tabel auditing yang bersesuaian. Engine sinkronisasi akan bekerja terhadap tiga kondisi data manipulation event, yaitu insert, update, dan delete.

Gambar 2 menjelaskan bagaimana fungsi sinkronisasi pada engine bekerja untuk membangun auditing. Proses diawali dengan memilih staging table yang sesuai dengan table yang mengalami DML events pada database eksisting. Ketika terjadi perubahan data, maka fungsi akan melakukan fetching sebanyak data yang mengalami perubahan, baik insert, update maupun delete. Selanjutnya fungsi akan melakukan counting pada tabel sistem sumber berdasarkan ID dari data yang berubah. Jika proses counting yang dihasilkan bernilai nol, maka data yang berubah ter-record ke table auditing.

Membangun auditing berbasis sinkronisasi DBMS membutuhkan semua aktivitas DML seperti insert, update, dan delete. Auditing berbasis sinkronisasi DBMS memiliki satu kelemahan, dimana tidak semua aktivitas database dapat terekam, seperti aktivitas DCL dan DDL. Setiap tabel pada sistem sumber akan dibagi menjadi tiga events, masing-masing terdiri dari fungsi insert, update dan delete. Data masukan yang didapat kedalam table auditing merupakan data yang dihasilkan dari fungsi sinkronisasi dari setiap event DML yang terjadi pada database eksisting.

\section{Kajian Pustaka}

\subsection{Database Auditing}

Auditing pada dasarnya merupakan kegiatan untuk memonitoring dan merekam kegiatan dari database pengguna yang ditentukan. Hasil dari auditing yang dihasilkan adalah berupa audit trail. Isi dari audit trail meliputi catatan yang memberitahu apa saja kejadian yang terjadi pada database. Tingkat record atau perekaman kejadian yang mampu ditangani setiap DBMS memiliki batasan masing-masing. [8] Meg Coffin Murray menjelaskan bahwa, database auditing 
dapat digunakan untuk mengidentifikasikan siapa yang mengakses database, kegiatan apa yang dilakukan, dan data apa yang diubah.

Meng-audit aktivitas dan akses terhadap database dapat membantu mengidentifikasi masalah keamanan basis data dan menyelesaikannya dengan cepat. Auditing sebagai suatu fungsi, memainkan peran sentral dalam memastikan kepatuhan terhadap aturan karena audit memeriksa dokumentasi tindakan, praktik, dan perilaku bisnis atau individu [7].

Salah satu kunci keberhasilan auditing adalah untuk dapat melacak perubahan jejak data, apa operasi modifikasi, dan kapan operasi itu terjadi melalui data historikal. Data historis dapat dimodelkan dalam database relasional, dalam beberapa teknik seperti tabel terpisah untuk catatan historis, log transaksi, dan data multi-dimensional. Untuk menjaga historis data dalam auditing, beberapa teknik yang disarankan dapat diimplementasikan, seperti Row-based Auditing atau Column-based Auditing [3].

\subsubsection{Auditing Dengan Row-Based}

[3] Teknik ini membuat tabel terpisah dalam setiap tabel relasional untuk menjaga historis data. Tabel operasional tetap sama seperti pada sistem non-auditing. Tabel operasional hanya mempertahankan nilai sekarang dari setiap nilai untuk operasi bisnis. Tabel tersebut juga mencakup data statis dan data historis. Data statis tetap tidak berubah atau data yang jarang berubah. Untuk data historis, hanya nilai terakhir yang diperbarui yang akan dipertahankan dalam tabel operasional.

\begin{tabular}{|c|c|c|c|c|c|c|c|c|c|c|}
\hline PK & ID & Name & DOB & Address & HiredDate & Salary & StartTime & EndTime & Operation & User \\
\hline 1 & 101 & Tom & 1980-01-01 & New York & 2008-01-01 & 50000 & 2008-01-01 & 2009-01-01 & I & Mike \\
\hline 2 & 101 & Tom & 1980-01-01 & New York & 2008-01-01 & 55000 & 2009-01-01 & & $\mathrm{U}$ & Mel \\
\hline 3 & 102 & Ann & 1985-06-16 & London & 2009-01-01 & 60000 & 2009-01-01 & & I & Mike \\
\hline 4 & 103 & Jack & 1975-01-01 & New York & 2008-01-01 & 60000 & 2008-01-01 & $2008-06-15$ & I & Mike \\
\hline 5 & 103 & Jack & 1975-01-01 & Hong Kong & 2008-01-01 & 60000 & 2008-06-15 & 2009-01-01 & $\mathrm{U}$ & Mike \\
\hline 6 & 103 & Jack & 1975-01-01 & Hong Kong & 2008-01-01 & 70000 & 2009-01-01 & $2009-05-31$ & $\mathrm{U}$ & Mel \\
\hline 7 & 103 & Jack & $1975-01-01$ & Hong Kong & $2008-01-01$ & 70000 & $2009-05-31$ & $2008-05-31$ & $\bar{D}$ & Matt \\
\hline
\end{tabular}

\section{Gambar 3. Row-based Auditing}

Tabel auditing berisi nilai dari setiap kolom tabel operasional seperti yang ditunjukkan pada Gambar 3. Untuk mengurangi operasi query join, data statis disertakan dalam tabel auditing. Dua timestamp waktu dibutuhkan untuk waktu valid, yaitu start time dan end time untuk mempertahankan umur data. Tipe operasi dicatat untuk mengurangi perbandingan antara historis data yang sama.

\subsubsection{Auditing Dengan Column-Based}

[3] Auditing berbasis kolom memecahkan redundansi dari auditing berbasis baris. Data dalam historis kolom dari tabel auditing hanya menyimpan nilai yang berubah kecuali primary key, seperti ID, yang digunakan untuk referensi pada tabel operasional. Setiap record dalam tabel auditing berbasis kolom tidak boleh berisi lebih dari satu nilai data historis karena adanya ketidakpastian terhadap waktu berakhir (time end) dari setiap data auditing.

\begin{tabular}{|c|c|c|c|c|c|c|c|}
\hline PK & ID & Address & Salary & StartTime & EndTime & $\begin{array}{c}\text { Opera- } \\
\text { tion }\end{array}$ & User \\
\hline 1 & 101 & New York & & 2008-01-01 & & I & Mike \\
\hline 2 & 101 & & 50000 & 2008-01-01 & 2009-01-01 & I & Mike \\
\hline 3 & 101 & & 55000 & 2009-01-01 & & $\mathrm{U}$ & $\mathrm{Mel}$ \\
\hline 4 & 102 & London & & 2009-01-01 & & I & Mike \\
\hline 5 & 102 & & 60000 & 2009-01-01 & & I & Mike \\
\hline 6 & 103 & New York & & 2008-01-01 & 2008-06-15 & I & Mike \\
\hline 7 & 103 & & 60000 & 2008-01-01 & 2009-01-01 & I & Mike \\
\hline 8 & 103 & $\begin{array}{l}\text { Hong } \\
\text { Kong }\end{array}$ & & 2008-06-15 & & $\mathrm{U}$ & Mike \\
\hline 9 & 103 & & 70000 & 2009-01-01 & & $\mathrm{U}$ & Mel \\
\hline 10 & 103 & & & $2009-05-31$ & & D & Matt \\
\hline
\end{tabular}

Gambar 4. Column-based Auditing 


\subsection{Sinkronisasi Database}

Sinkronisasi database merupakan proses yang bertujuan menjaga ketetapan atau kosistensi data yang terdapat pada database server terhadap data yang berada pada database server lainnya. Terdapat fungsi penyalinan data (copying) dalam sinkronisasi database, yang tersimpan pada suatu tabel database lain, baik secara periodik maupun secara real-time. Adanya fungsi sinkronisasi database memungkinkan perbaharuan data secara real-time atau berkala pada database yang menjadi objek sinkronisasi. Fungsi sinkronisasi ini merupakan suatu dasar dari adanya replikasi pada DBMS (Database Management System) [9].

Sinkronisasi merupakan bagian dari replikasi database, merupakan sebuah teknik dalam pendistribusian dan penyalinan data antar database sehingga ketetapan atau konsistensi data pada suatu database terjaga [10]. Fungsi sinkronisasi memungkinkan pendistribusian data dilakukan secara periodik pada rentang waktu tertentu atau real-time ke host yang berbeda melalui jaringan komputer. Sinkronisasi database dapat mendukung berjalannya fungsi dari aplikasi bisnis, pendistribusian data untuk berbagai keperluan, diantaranya meningkatkan kinerja transaksi bisnis, sistem pengambilan keputusan atau pengolahan sistem terdistribusi pada server yang berbeda [9].

\subsection{SIDEKA (Sistem Informasi Desa dan Kawasan)}

Sistem Informasi Desa dan Kawasan (SIDEKA) merupakan sistem informasi manajemen data desa pada Desa Tangkas, Kabupaten Klungkung, meliputi manajemen data penduduk, data wilayah, dll. Pengaksesan data berupa meng-entry data master serta melihat berbagai riwayat data.

\subsection{Database Management System (DBMS)}

Database Management System (DBMS) merupakan aplikasi komputer yang memiliki fungsi dalam melakukan manajemen data meliputi proses pemasukkan (insert), pengubahan/modifikasi (update), penghapusan (delete), serta memperoleh data / informasi (select) sesuai kebutuhan. Keunggulan dari adanya DBMS sebagai media manajemen data adalah sebagai berikut [9].

1. Praktis: DBMS memberikan fitur media penyimpan data secara permanen dengan ukuran kecil tetapi dapat menyimpan banyak data.

2. Cepat: DBMS sebagai aplikasi komputer dapat mencari dan menampilkan informasi yang dibutuhkan dengan cepat dan akurat.

3. Up-to-date: Informasi yang tersedia selalu berubah dan akurat setiap saat.

DBMS dapat di kelompokkan menjadi DBMS homogen dan DMBS heterogen. Sistem DBMS homogen, berisi seluruh site menggunakan produk DBMS yang sama. Sedangkan sistem DBMS heterogen, terdiri dari produk DBMS yang beragam, termasuk pada model data yang tidak seragam, sehingga sistem DBMS heterogen terdiri dari beberapa macam model data seperti relasional, jaringan, hirarki dan object-oriented DBMS [9].

\section{Analisa Hasil dan Pembahasan}

Memuat analisa hasil dan pembahasan penelitian yang disajikan dalam bentuk deskripsi penjelasan dari setiap sub bab.

\subsection{Analisa Sistem Eksisting}

Sistem eksisting yang digunakan sebagai studi kasus database auditing adalah SIDEKA (Sistem Informasi Desa dan Kawasan). Sistem ini memiliki dua tabel yang dikelola yaitu, tabel keluarga dan tabel penduduk yang menjadi objek dalam proses auditing.

\subsection{Desain Auditing}

Berdasarkan beberapa tipe database auditing yang ada, penelitian ini menerapkan model Rowbased Auditing. Model ini menggunakan tabel auditing terpisah dari tabel operasional yang ada (eksisting) untuk melakukan proses auditing. Tabel auditing berisi nilai dari setiap kolom pada 
tabel eksisting yang disajikan secara historis dengan tambahan beberapa atribut diantaranya flag, time begin, time end, dan st code seperti yang ditunjukkan pada Gambar 5 dan Gambar 6.

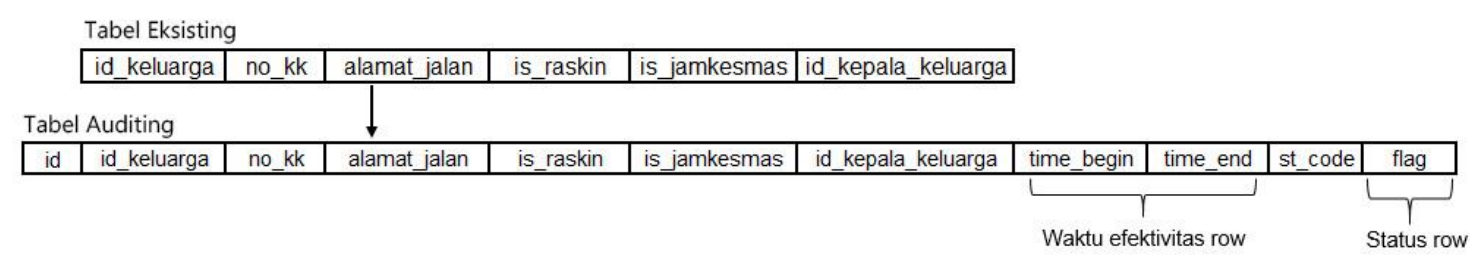

Gambar 5. Desain Auditing Tabel Keluarga

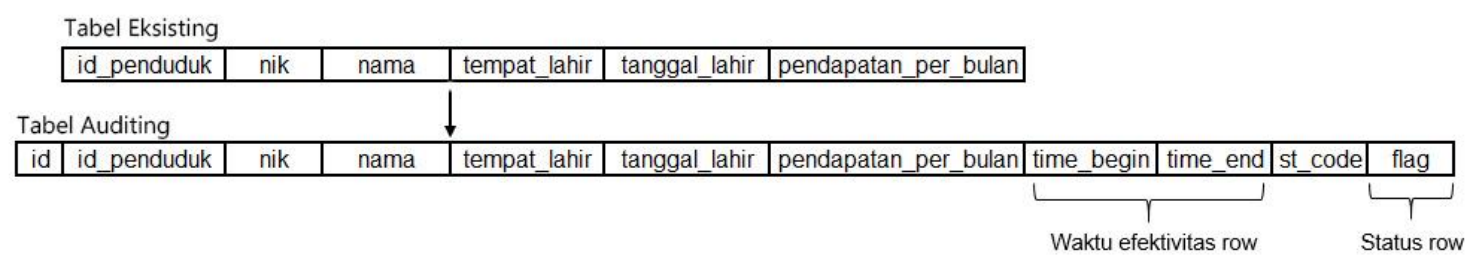

Gambar 6. Desain Auditing Tabel Penduduk

Model row-based auditing ini menyederhanakan pelaksanaan dari proses audit. Ketika pernyataan DML seperti insert, update, dan delete dijalankan pada tabel operasional, engine sinkronisasi hanya dapat menyalin setiap nilai dalam catatan ke dalam tabel auditing. Pada saat yang sama, kolom "time_end" dari historis sebelumnya harus diperbarui bersamaan dengan waktu operasi terjadi.

\subsection{Pengujian Hasil}

Pengujian auditing ini dilakukan dengan proses manipulasi data pada database eksisting SIDEKA (Sistem Informasi Desa dan Kawasan) yang mempengaruhi database staging dalam proses sinkronisasi dan mengirim perubahan data ke database auditing. Untuk pengujian proses insert, pengujian dilakukan dengan memasukkan data pada tabel keluarga melalui aplikasi DBMS client SQLyog seperti yang ditunjukan pada Gambar 7 dan Gambar 8 berikut.

\begin{tabular}{|c|c|c|c|c|c|c|}
\hline id_keluarga & no_kk & alamat_jalan & & & is_jamkesmas & id_kepala_keluarga \\
\hline 1 & 5105031807072456 & DUSUN PEKEN DESA TANGKAS & N & $-\mathrm{N}$ & N & 1 \\
\hline 2 & 5105031807072500 & DUSUN TUSAN DESA TANGKAS & $\mathrm{N}$ & $-\mathrm{N}$ & N & 5 \\
\hline 3 & 5105032606120001 & DUSUN PEKEN DESA TANGKAS & $\mathrm{N}$ & $-\mathrm{N}$ & $\mathrm{N}$ & 11 \\
\hline 4 & 5105030102100004 & DUSUN AMBENGAN DESA TANGKAS & N & $-\mathrm{N}$ & N & 13 \\
\hline 5 & 5105031807072496 & DUSUN AMBENGAN DESA TANGKAS & N & $-\mathrm{N}$ & N & 15 \\
\hline 6 & 5105031807072497 & DUSUN TUSAN DESA TANGKAS & $\mathrm{N}$ & $-\mathrm{N}$ & $\mathrm{N}$ & 18 \\
\hline 7 & 5105031807072498 & DUSUN MERANGGEN DESA TANGKAS & $\mathrm{N}$ & $-\mathrm{N}$ & N & 20 \\
\hline 8 & 5105031807072549 & DUSUN MERANGGEN DESA TANGKAS & $\mathrm{N}$ & $-\mathrm{N}$ & N & 24 \\
\hline 9 & 5105031807072484 & DUSUN PEKEN DESA TANGKAS & $\mathrm{N}$ & -1 & N & 30 \\
\hline 368 & 5105031807072438 & DUSUN TUSAN DESA TANGKAS & N & $-\mathrm{N}$ & $\mathrm{N}$ & 15 \\
\hline
\end{tabular}

Gambar 7. Hasil Insert Pada Tabel Keluarga Eksisting

\begin{tabular}{|c|c|c|c|c|c|}
\hline id_penduduk & nik & nama & tempat_lahir & tanggal_lahir & pendapatan_per_bulan \\
\hline & 5105030710700001 & I WAYAN NADRASH & TANGKAS & $1970-10-07 \quad 00: 00: 00$ & 3000000 \\
\hline & 55105030107600004 & I WAYAN TIKA SH & KLUNGKUNG & $1960-12-1200: 00: 00$ & 1200000 \\
\hline & 75105032004880001 & I GEDE JUSTIKA KORI & KLUNGKUNG & $1988-04-2000: 00: 00$ & 1500000 \\
\hline & 5105030610910001 & I MADE DWIJA PARAMARTHA KORI & KLUNGKUNG & $1991-10-0600: 00: 00$ & 1500000 \\
\hline & 95105030107380060 & I KETUT WANDRIS & IANGKAS & $1938-12-3100: 00: 00$ & 2000000 \\
\hline 10 & 5105034107380087 & NI WAYAN ASIH & TANGKAS & $1938-12-3100: 00: 00$ & 500000 \\
\hline 11 & 5115133112400089 & I NENGAH KAYUN & TANGKAS & $1940-12-3100: 00: 00$ & 2500000 \\
\hline 13 & 5105033112470074 & I NENGAH TISTA & TANGKAS & $1947-12-3100: 00: 00$ & 1500000 \\
\hline 14 & 5105037112510098 & NI WAYAN PURNI & GELGEL & $1970-01-0100: 00: 00$ & 1300000 \\
\hline 15 & 5105033112720022 & I KETUT SUCANA & TANGKAS & $1972-12-3100: 00: 00$ & 1700000 \\
\hline 1340 & 5105033112728742 & I MADE BELAYU & TANGKAS & $1988-06-14 \quad 00: 00: 00$ & 2000000 \\
\hline
\end{tabular}

Gambar 8. Hasil Insert Pada Tabel Penduduk Eksisting 
Hasil insert pada tabel keluarga ditunjukkan pada row dengan "id_keluarga" bernilai "368", serta hasil insert pada tabel penduduk dengan "id_penduduk" bernilai "1340". Saat proses insert terjadi pada tabel eksisting, engine akan mengidentifikasi proses DML yang terjadi dan memicu engine untuk melakukan sinkronisasi pada tabel yang bersesuaian didalam database staging serta menyimpan perubahan data kedalam tabel auditing. Gambar 9 menunjukkan engine menangkap event DML dari proses insert yang dilakukan pada tabel keluarga.

\begin{tabular}{|c|}
\hline 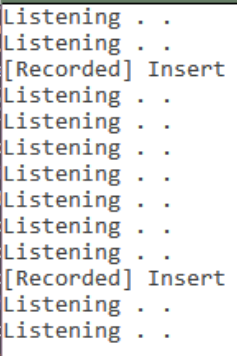 \\
\hline
\end{tabular}

Gambar 9. Engine Bekerja Menangkap Perubahan Insert Pada Tabel Eksisting

Dalam waktu yang bersamaan, engine akan me-record aktivitas DML insert yang terjadi pada tabel keluarga dan tabel penduduk lalu menyimpannya sebagai row baru didalam tabel auditing beserta beberapa atribut tambahan diantaranya field "time_begin" dan "time_end" untuk mengetahui umur atau efektivitas dari suatu row/data, field "st_code" untuk mengidentifikasi proses DML yang terjadi dari data/row tersebut serta field "flag" untuk mengetahui data aktif/non-aktif.

\begin{tabular}{|c|c|c|c|c|c|c|c|c|c|}
\hline id & d keluarga no $\mathrm{kk}$ & alamat_jalan & is_raskin & is jamkesmas & id kepala keluarga & time begin & time end & st code & flag \\
\hline 4371 & 5105031807072456 & DUSUN PEKEN DESA TANGKAS & $\mathrm{N}^{-}$ & $-\pi$ & & $12017-06-07 \quad 15: 22: 54$ & $0000-00-00 \quad 00: 00: 00$ & $I^{-}$ & \\
\hline 4382 & 5105031807072500 & DUSUN TUSAN DESA TANGKAS & N & - $\mathrm{N}$ & & $52017-06-07 \quad 15: 22: 54$ & $0000-00-0000: 00: 00$ & I & 1 \\
\hline 4393 & 5105032606120001 & DUSUN PEKEN DESA TANGKAS & $\mathbb{N}$ & $\because \mathrm{N}$ & & $112017-06-07 \quad 15: 22: 54$ & $0000-00-00 \quad 00: 00: 00$ & I & \\
\hline 4404 & 5105030102100004 & DUSUN AMBENGAN DESA TANGKAS & N & $\rightarrow \mathrm{N}$ & & $132017-06-07 \quad 15: 22: 54$ & $0000-00-00 \quad 00: 00: 00$ & I & 1 \\
\hline 4415 & 5105031807072496 & DUSUN AMBENGAN DESA TANGKAS & N & N & & $15 \quad 2017-06-07 \quad 15: 22: 54$ & $0000-00-00 \quad 00: 00: 00$ & I & 1 \\
\hline 4426 & 5105031807072497 & DUSUN TUSAN DESA TANGKAS & N & $\rightarrow \mathbb{N}$ & & $182017-06-07 \quad 15: 22: 54$ & $0000-00-00 \quad 00: 00: 00$ & I & 1 \\
\hline 4437 & 5105031807072498 & DUSUN MERANGGEN DESA TANGKAS & N & $\rightarrow \mathrm{N}$ & & $202017-06-07 \quad 15: 22: 54$ & $0000-00-00 \quad 00: 00: 00$ & I & 1 \\
\hline 4448 & 5105031807072549 & DUSUN MERANGGEN DESA TANGKAS & N & $\mathrm{N}$ & & $242017-06-07 \quad 15: 22: 54$ & $0000-00-00 \quad 00: 00: 00$ & I & 1 \\
\hline 4459 & 5105031807072484 & DUSON PEKEN DESA TANGKAS & N & N & & $302017-06-07 \quad 15: 22: 54$ & $0000-00-0000000: 00$ & I & 1 \\
\hline 446368 & 5105031807072438 & DUSUN TUSAN DESA TANGKAS & $\mathbb{N}$ & $\sqrt{N}$ & & $15 \quad 2017-06-07 \quad 15: 24: 36$ & $0000-00-00 \quad 00: 00: 00$ & I & 1 \\
\hline
\end{tabular}

Gambar 10. Hasil Proses Insert Auditing Untuk Tabel Keluarga

\begin{tabular}{|c|c|c|c|c|c|c|c|c|c|}
\hline id & id_penduduk nik & nama & tempat_1.. & tanggal_lahir & pendapatan_per_bulan time_begin & & time_end & st_code & flag \\
\hline 1372 & 15105030710700001 & I WAYAN NADRASH & TANGKĀS & $1970-10-07 \quad 00: 00: 00$ & $30000002017-06-07$ & $15: 22: 54$ & $0000-00-00 \quad 00: 00: 00$ & I & 1 \\
\hline 1373 & 55105030107600004 & I WAYAN TIKA SH & KLUNGKUNG & $1960-12-12 \quad 00: 00: 00$ & $12000002017-06-07$ & $15: 22: 54$ & $0000-00-00 \quad 00: 00: 00$ & I & \\
\hline 1374 & 75105032004880001 & I GEDE JUSTIKA KORI & KLUNGKUNG & $1988-04-2000: 00: 00$ & $15000002017-06-07$ & $15: 22: 54$ & $0000-00-00 \quad 00: 00: 00$ & I & \\
\hline 1375 & 85105030610910001 & I MADE DWIJA PARAMARTHA KORI & KLUNGKUNG & $1991-10-0600: 00: 00$ & $15000002017-06-07$ & $15: 22: 54$ & $0000-00-00 \quad 00: 00: 00$ & I & 1 \\
\hline 1376 & 95105030107380060 & I KETUI WANDRIS & TANGKAS & $1938-12-3100: 00: 00$ & $20000002017-06-07$ & $15: 22: 54$ & $0000-00-00 \quad 00: 00: 00$ & I & 1 \\
\hline 1377 & 105105034107380087 & NI WAYAN ASIH & tamgkas & $1938-12-31 \quad 00: 00: 00$ & $5000002017-06-07$ & $15: 22: 54$ & $0000-00-0000: 00: 00$ & I & 1 \\
\hline 1378 & 115115133112400089 & I IENGAH KAYYN & TaMGKas & $1940-12-31 \quad 00: 00: 00$ & $25000002017-06-07$ & $15: 22: 55$ & $0000-00-00 \quad 00: 00: 00$ & I & 1 \\
\hline 1379 & 135105033112470074 & I NENGAH TISTA & TAMGKas & $1947-12-31 \quad 00: 00: 00$ & $15000002017-06-07$ & $15: 22: 55$ & $0000-00-00 \quad 00: 00: 00$ & I & 1 \\
\hline 1380 & 145105037112510098 & WII WAYAN PURNI & GELGEL & $1970-01-01 \quad 00: 00: 00$ & $13000002017-06-07$ & $15: 22: 55$ & $0000-00-0000: 00: 00$ & I & 1 \\
\hline 1381 & 155105033112720022 & I KETUT SUCANA & TAMGKAS & $1972-12-31 \quad 00: 00: 00$ & $17000002017-06-07$ & $15: 22: 55$ & $0000-00-00 \quad 00: 00: 00$ & I & 1 \\
\hline 1382 & 13405105033112728742 & I MADE BELAYU & TANGKAS & $1988-06-14 \quad 15: 26: 39$ & $20000002017-06-07$ & $15: 27: 04$ & $0000-00-00 \quad 00: 00: 00$ & I & 1 \\
\hline
\end{tabular}

Gambar 11. Hasil Proses Insert Auditing Untuk Tabel Penduduk

Gambar 10. dan Gambar 11. menunjukkan data hasil insert pada tabel keluarga eksisting dengan "id_keluarga" = "368" dan pada tabel penduduk dengan "id_penduduk" = "1340", telah tersimpan sebagai historis data didalam tabel auditing. Pengujian selanjutnya yaitu event DML update yang akan di ujicoba pada tabel yang sama yaitu pada tabel keluarga dan tabel penduduk seperti yang ditunjukkan pada Gambar 12 dan Gambar 13. 


\begin{tabular}{|c|c|c|c|c|c|c|c|}
\hline id_keluarga & no_kk & alamat_jalan & & & is_jamkesmas & & id_kepala_keluarga \\
\hline 1 & 5105031807072456 & DUSUN PEKEN DESA TANGKAS & N & $-\mathrm{r}$ & N & $v$ & 1 \\
\hline 2 & 5105031807072500 & DUSUN TUSAN DESA TANGKAS & N & $-\mathrm{N}$ & N & + & 5 \\
\hline 3 & 5105032606120001 & DUSUN PEKEN DESA TANGKAS & N & $\cdot \mathrm{r}$ & N & - & 11 \\
\hline 4 & 5105030102100004 & DUSUN AMBENGAN DESA TANGKAS & N & $\rightarrow \mathrm{N}$ & N & - & 13 \\
\hline 5 & 5105031807072496 & DUSUN AMBENGAN DESA TANGKAS & N & $\rightarrow \mathrm{r}$ & N & 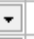 & 15 \\
\hline 6 & 5105031807072497 & DUSUN TUSAN DESA TANGKAS & N & $-\mathrm{r}$ & N & - & 18 \\
\hline 7 & 5105031807072498 & DUSUN MERANGGEN DESA TANGKAS & N & $-\mathrm{r}$ & N & 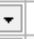 & 20 \\
\hline 8 & 5105031807072549 & DUSUN MERANGGEN DESA TANGKAS & N & $-\mathrm{r}$ & N & - & 24 \\
\hline 9 & 5105031807072484 & DUSUN PEKEN DESA TANGKAS & N & -1 & N & - & 30 \\
\hline 368 & 5105031807072438 & DUSUN AMBENGAN DESA TANGKAS & $\mathrm{Y}$ & $\cdot y$ & Y & - & 15 \\
\hline
\end{tabular}

Gambar 12. Hasil Update Pada Tabel Keluarga Eksisting

\begin{tabular}{|c|c|c|c|c|c|}
\hline id_penduduk & nik & nama & tempat_lahir & tanggal_lahir & pendapatan_per_bulan \\
\hline 1 & 5105030710700001 & I WAYAN NADRASH & TANGKAS & $1970-10-07 \quad 00: 00: 00$ & 3000000 \\
\hline 5 & 5105030107600004 & I WAYAN TIKA SH & KLUNGKUNG & $1960-12-12 \quad 00: 00: 00$ & 1200000 \\
\hline & 5105032004880001 & I GEDE JUSTIKA KORI & KLUNGKUNG & $1988-04-20 \quad 00: 00: 00$ & 1500000 \\
\hline 8 & 5105030610910001 & I MADE DWIJA PARAMARTHA KORI & KLUNGKUNG & $1991-10-06 \quad 00: 00: 00$ & 1500000 \\
\hline 9 & 5105030107380060 & I KETUT WANDRIS & TANGKAS & $1938-12-3100: 00: 00$ & 2000000 \\
\hline 10 & 5105034107380087 & NI WAYAN ASIH & TANGKAS & $1938-12-3100: 00: 00$ & 500000 \\
\hline 11 & 5115133112400089 & I NENGAH KAYUN & TANGKAS & $1940-12-31 \quad 00: 00: 00$ & 2500000 \\
\hline 13 & 5105033112470074 & I NENGAH TISTA & TANGKAS & $1947-12-31 \quad 00: 00: 00$ & 1500000 \\
\hline 14 & 5105037112510098 & NI WAYAN PURNI & GELGEL & $1970-01-01 \quad 00: 00: 00$ & 1300000 \\
\hline 15 & 5105033112720022 & I KETUT SUCANA & TANGKAS & $1972-12-3100: 00: 00$ & 1700000 \\
\hline 1340 & 5105033112728742 & I MADE BELAYU & TANGKAS & $1988-06-1400: 00: 00$ & 3000000 \\
\hline
\end{tabular}

Gambar 13. Hasil Update Pada Tabel Penduduk Eksisting

Hasil update pada tabel keluarga ditunjukkan pada row dengan "id_keluarga" bernilai "368", serta hasil update pada tabel penduduk dengan "id_penduduk" bernilai "1340". Proses update pada tabel keluarga dilakukan dengan memaipulasi beberapa field yaitu "alamat jalan", "is_raskin" dan "is_jamkesmas" dengan masing-masing nilai "DUSUN AMBENGAN DESA TANGKAS", "Y", dan "Y". Sementara itu proses update pada tabel penduduk dilakukan dengan memaipulasi field "pendapatan_per_bulan" dengan nilai "3000000" melalui aplikasi diatas.

Saat proses update terjadi pada tabel eksisting, engine akan mengidentifikasi proses DML yang terjadi dan memicu engine untuk melakukan sinkronisasi pada tabel yang bersesuaian didalam database staging serta menyimpan perubahan data kedalam tabel auditing.

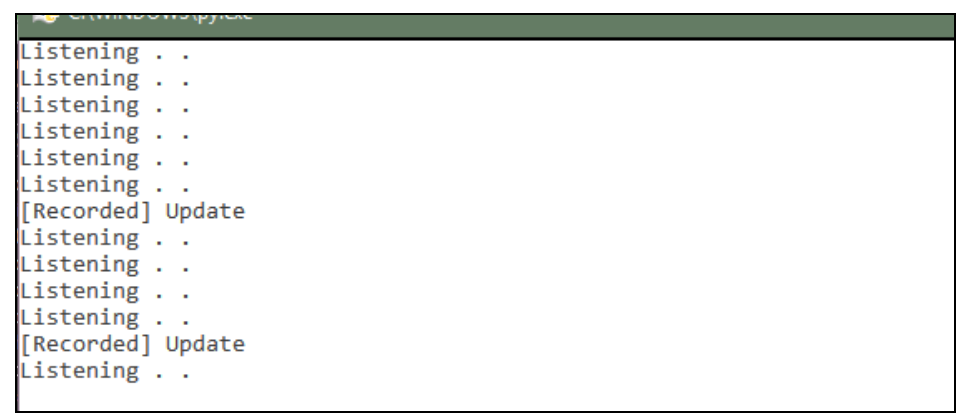

Gambar 14. Engine Bekerja Menangkap Perubahan Update Pada Tabel Eksisting

Update event yang terjadi pada tabel eksisting memicu engine untuk merekam perubahan data yang terjadi pada sistem sumber kedalam tabel auditing seperti yang ditampilkan pada Gambar 15 dan Gambar 16. 


\begin{tabular}{|c|c|c|c|c|c|c|c|c|c|}
\hline id_ & no_kk & alamat_jalan & is_raskin & n is_jamkesmas & id_kepala_keluarga & time_begin & time_end & st_code & flag \\
\hline 4371 & 5105031807072456 & DUSUN PEKEN DESA TANGKAS & $\mathbb{N} \quad[-1$ & $\cdot \mathbb{N}$ & 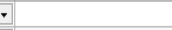 & $12017-06-07 \quad 15: 22: 54$ & $0000-00-0000: 00: 00$ & I & 1 \\
\hline 4382 & 5105031807072500 & DUSUN TUSAN DESA TANGKAS & $\mathbb{N}$ & $\cdot \mathbb{N}$ & - & 5 2017-06-07 15:22:54 & $0000-00-0000: 00: 00$ & I & 1 \\
\hline 4393 & 5105032606120001 & DUSUN PEKEN DESA TANGKAS & $\mathbb{N}$ & $\cdot \mathbb{N}$ & - & 11 2017-06-07 15:22:54 & $0000-00-00 \quad 00: 00: 00$ & I & 1 \\
\hline 4404 & 5105030102100004 & DUSUN AMBENGAN DESA TANGKAS & $\mathbb{N}$ & $\cdot \mathbb{N}$ & - & $132017-06-07 \quad 15: 22: 54$ & $0000-00-0000: 00: 00$ & I & 1 \\
\hline 4415 & 5105031807072496 & DUSUN AMBENGAN DESA TANGKAS & $\mathbb{N}$ & $\cdot \mathbb{N}$ & - & 15 2017-06-07 15:22:54 & $0000-00-0000: 00: 00$ & I & 1 \\
\hline 4426 & 5105031807072497 & DUSON TUSAN DESA TANGKAS & $\mathbb{N}$ & $\sqrt{\mathbb{N}}$ & 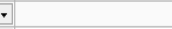 & $18 \quad 2017-06-07 \quad 15: 22: 54$ & $0000-00-00 \quad 00: 00: 00$ & I & 1 \\
\hline 4437 & 5105031807072498 & DUSUN MERANGGEN DESA TANGKAS & $\mathbb{N}$ & $\cdot \mathbb{N}$ & - & 20 2017-06-07 15:22:54 & $0000-00-00 \quad 00: 00: 00$ & I & 1 \\
\hline 4448 & 5105031807072549 & DUSUN MERANGGEN DESA TANGKAS & $\mathbb{N}$ & $-\mathbb{N}$ & - & $24 \quad 2017-06-07 \quad 15: 22: 54$ & $0000-00-0000: 00: 00$ & I & 1 \\
\hline 4459 & 5105031807072484 & DUSUN PEKEN DESA TANGKAS & $\mathbb{N}$ & $\cdot \mathbb{N}$ & . & $302017-06-07 \quad 15: 22: 54$ & $0000-00-0000: 00: 00$ & I & 1 \\
\hline 446368 & 5105031807072438 & DUSON TUSAN DESA TANGKAS & $\mathbb{N}$ & $\cdot \mathbb{N}$ & - & 15 2017-06-07 15:24:36 & $2017-06-07 \quad 15: 54: 29$ & I & 0 \\
\hline 448368 & 5105031807072438 & DUSUN AMBENGAN DESA TANGKAS & Y & $\nabla Y$ & - & $152017-06-07 \quad 15: 54: 29$ & $0000-00-00 \quad 00: 00: 00$ & 0 & 1 \\
\hline
\end{tabular}

Gambar 15. Hasil Proses Update Auditing Untuk Tabel Keluarga

\begin{tabular}{|c|c|c|c|c|c|c|c|c|c|}
\hline di & id_penduduk $\mathrm{nik}$ & nama & tempat_1. & tanggal_lahir & pendapatan_per_bulan time_begin & & time_end & st_code & flag \\
\hline 1372 & 15105030710700001 & I WAYAN NADRASH & TANGKAS & $1970-10-0700: 00: 00$ & $30000002017-06-07$ & $15: 22: 54$ & $0000-00-00 \quad 00: 00: 00$ & $I^{-}$ & 1 \\
\hline 1373 & 55105030107600004 & I WAYAN TIKA SH & KLUNGKUNG & $1960-12-1200: 00: 00$ & $12000002017-06-07$ & $15: 22: 54$ & $0000-00-00 \quad 00: 00: 00$ & & \\
\hline 1374 & 75105032004880001 & I GEDE JUSTTKA KORI & KLUNGKONG & $1988-04-2000: 00: 00$ & $15000002017-06-07$ & $15: 22: 54$ & $0000-00-0000: 00: 00$ & I & 1 \\
\hline 1375 & 85105030610910001 & I MADE DNT JA PARAMARTHA KORT & KLTUGKTITG & $1991-10-0600 ; 00 ; 00$ & $15000002017-06-07$ & $15: 22: 54$ & $0000-00-0000 ; 00 ; 00$ & T & 1 \\
\hline 1376 & 95105030107380060 & I KETUI WANDRIS & TANGKAS & $1938-12-31 \quad 00: 00: 00$ & $20000002017-06-07$ & $15: 22: 54$ & $0000-00-00 \quad 00: 00: 00$ & 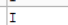 & 1 \\
\hline 1377 & 105105034107380087 & NI WAYAN ASIH & TANGKAS & $1938-12-3100: 00: 00$ & $5000002017-06-07$ & $15: 22: 54$ & $0000-00-0000: 00: 00$ & I & 1 \\
\hline 1378 & 115115133112400089 & I NENGAH KAYUN & TANGKAS & $1940-12-3100: 00: 00$ & $25000002017-06-07$ & $15: 22: 55$ & $0000-00-0000: 00: 00$ & I & 1 \\
\hline 1379 & 135105033112470074 & I NENGAH TISTA & TANGKAS & $1947-12-3100: 00: 00$ & $15000002017-06-07$ & $15: 22: 55$ & $0000-00-00 \quad 00: 00: 00$ & I & 1 \\
\hline 1380 & 145105037112510098 & NTT WAYAN PURNT & GEIGEL & $1970-01-0100: 00: 00$ & $13000002017-06-07$ & $15: 22: 55$ & $0000-00-0000000: 00$ & I & 1 \\
\hline 1381 & 155105033112720022 & I KETUT SUCANA & TANGKAS & $1972-12-3100: 00: 00$ & $17000002017-06-07$ & $15: 22: 55$ & $0000-00-00 \quad 00: 00: 00$ & I & 1 \\
\hline 1382 & 13405105033112728742 & I MADE BELAYU & TANGKAS & $1988-06-14 \quad 00: 00: 00$ & $20000002017-06-07$ & $15: 27: 04$ & $2017-06-07 \quad 16: 06: 33$ & I & 0 \\
\hline 1383 & 13405105033112728742 & I MADE BELAYU & TANGKAS & $1988-06-1400: 00: 00$ & $30000002017-06-07$ & $16: 06: 33$ & $0000-00-0000: 00: 00$ & $\mathrm{U}$ & 1 \\
\hline
\end{tabular}

Gambar 16. Hasil Proses Update Auditing Untuk Tabel Penduduk

Gambar 15. dan Gambar 16. menunjukkan data hasil update pada tabel keluarga dengan "id_keluarga" = "368" dan pada tabel penduduk dengan "id_penduduk" = "1340", tersimpan secara historis sebagai row baru didalam tabel auditing. Data hasil update pada tabel eksisting menunjukan bahwa data tersebut bernilai aktif menggantikan rekaman data hasil insert pada proses sebelumnya, yang ditunjukkan dengan field "flag" bernilai "1".

Pengujian selanjutnya yaitu event DML delete yang akan di ujicoba pada tabel yang sama yaitu pada tabel keluarga dan tabel penduduk seperti yang ditampilkan pada Gambar 17 dan Gambar 18.

\begin{tabular}{|c|c|c|c|c|c|c|c|c|}
\hline id_keluarga & & no_kk & alamat_jalan & & & is_jamkesmas & & id_kepala_keluarga \\
\hline & 1 & 5105031807072456 & DUSUN PEKEN DESA TANGKAS & N & - 1 & N & $\rightarrow$ & 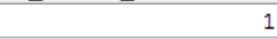 \\
\hline & 2 & 5105031807072500 & DUSUN TUSAN DESA TANGKAS & N & $\rightarrow 1$ & $\mathrm{~N}$ & - & 5 \\
\hline & 3 & 5105032606120001 & DUSUN PEKEN DESA TANGKAS & N & -1 & N & 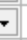 & 11 \\
\hline & 4 & 5105030102100004 & DUSUN AMBENGAN DESA TANGKAS & N & +1 & N & $\checkmark$ & 13 \\
\hline & 5 & 5105031807072496 & DUSUN AMBENGAN DESA TANGKAS & N & -1 & N & - & 15 \\
\hline & 6 & 5105031807072497 & DUSUN TUSAN DESA TANGKAS & $\mathrm{N}$ & +1 & N & - & 18 \\
\hline & 7 & 5105031807072498 & DUSUN MERANGGEN DESA TANGKAS & $\mathrm{N}$ & +1 & N & - & 20 \\
\hline & 8 & 5105031807072549 & DUSUN MERANGGEN DESA TANGKAS & N & $\cdot 1$ & N & - & 24 \\
\hline & 9 & 5105031807072484 & DUSUN PEKEN DESA TANGKAS & N & -1 & N & - & 30 \\
\hline
\end{tabular}

Gambar 17. Hasil Delete Pada Tabel Keluarga Eksisting

\begin{tabular}{|c|c|c|c|c|c|c|}
\hline id_penduduk & & nik & nama & tempat_lahir & tanggal_lahir & pendapatan_per_bulan \\
\hline & & 5105030710700001 & I WAYAN NADRASH & TANGKAS & $1970-10-07 \quad 00: 00: 00$ & 3000000 \\
\hline & & 5105030107600004 & I WAYAN TIKA SH & KLUNGKUNG & $1960-12-1200: 00: 00$ & 1200000 \\
\hline & & 5105032004880001 & I GEDE JUSTIKA KORI & KLUNGKUNG & $1988-04-20 \quad 00: 00: 00$ & 1500000 \\
\hline & & 5105030610910001 & I MADE DWIJA PARAMARTHA KORI & KLUNGKUNG & $1991-10-06 \quad 00: 00: 00$ & 1500000 \\
\hline & & 5105030107380060 & I KETUT WANDRIS & TANGKAS & $1938-12-31 \quad 00: 00: 00$ & 2000000 \\
\hline & 10 & 5105034107380087 & NI WAYAN ASIH & TANGKAS & $1938-12-31 \quad 00: 00: 00$ & 500000 \\
\hline & 11 & 5115133112400089 & I NENGAH KAYUN & TANGKAS & $1940-12-3100: 00: 00$ & 2500000 \\
\hline & 13 & 5105033112470074 & I NENGAH TISTA & TANGKAS & $1947-12-3100: 00: 00$ & 1500000 \\
\hline & 14 & 5105037112510098 & NI WAYAN PURNI & GELGEL & $1970-01-01 \quad 00: 00: 00$ & 1300000 \\
\hline & 15 & 5105033112720022 & I KETUT SUCANA & TANGKAS & $1972-12-31 \quad 00: 00: 00$ & 1700000 \\
\hline
\end{tabular}

Gambar 18. Hasil Delete Pada Tabel Penduduk Eksisting

Proses delete pada tabel keluarga dilakukan pada data dengan "id_keluarga" bernilai "368" seperti yang ditunjukkan pada Gambar 12, serta pada tabel penduduk pada data dengan "id_penduduk" bernilai "1340" seperti yang ditunjukkan pada Gambar 13. Saat proses delete terjadi pada tabel eksisting, fungsi pada engine akan mengidentifikasi proses DML yang terjadi 
dan memicu engine untuk melakukan sinkronisasi pada tabel yang bersesuaian didalam database staging serta menyimpan perubahan data kedalam tabel auditing sebagai row baru.

\begin{tabular}{|c|}
\hline 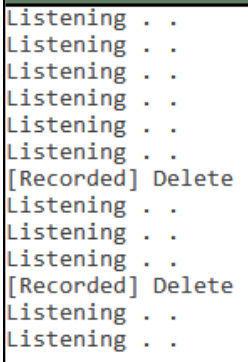 \\
\hline
\end{tabular}

\section{Gambar 19. Engine Bekerja Menangkap Perubahan Delete Pada Tabel Eksisting}

Proses delete yang terjadi pada tabel keluarga dan tabel penduduk ter-record sebagai row baru dalam table auditing seperti yang ditampilkan pada Gambar 20 dan Gambar 21.

\begin{tabular}{|c|c|c|c|c|c|c|c|c|c|c|c|}
\hline \multicolumn{2}{|c|}{ id_keluargal no_kk } & alamat_jalan & is_raskin & 13_jamkesmas & \multirow{2}{*}{ id_kepala_keluarga } & \multicolumn{2}{|c|}{ time_begin } & \multicolumn{2}{|c|}{ time_end } & \multirow{2}{*}{ st_code } & \multirow{2}{*}{$\begin{array}{l}\text { flag } \\
1\end{array}$} \\
\hline 4371 & 5105031807072456 & DUSUN PEKEN DESA TANGKAS & $\mathrm{N}$ & $-\pi$ & & $12017-06-07$ & $15: 22: 54$ & $0000-00-00$ & $00: 00: 00$ & & \\
\hline 4382 & 5105031807072500 & DUSUN TUSAN DESA TANGKAS & $\mathbb{N}$ & $\rightarrow \mathbb{N}$ & & $52017-06-07$ & $15: 22: 54$ & $0000-00-00$ & $00: 00: 00$ & I & 1 \\
\hline 4393 & 5105032606120001 & DUSUN PEKEN DESA TANGKAS & N & N & & $112017-06-07$ & $15: 22: 54$ & $0000-00-00$ & $00: 00: 00$ & I & 1 \\
\hline 4404 & 5105030102100004 & DUSUN AMBENGAN DESA TANGKAS & N & - $\mathbb{N}$ & & $132017-06-07$ & $15: 22: 54$ & $0000-00-00$ & $00: 00: 00$ & I & 1 \\
\hline 4415 & 5105031807072496 & DUSUN AMBENGAN DESA TANGKAS & N & $\checkmark \mathbb{N}$ & & $152017-06-07$ & $15: 22: 54$ & $0000-00-00$ & $00: 00: 00$ & I & 1 \\
\hline 4426 & 5105031807072497 & DUSUN TUSAN DESA TANGKAS & $\mathbb{N}$ & - $\mathbb{N}$ & & $182017-06-07$ & $15: 22: 54$ & $0000-00-00$ & $00: 00: 00$ & I & 1 \\
\hline 4437 & 5105031807072498 & DUSUN MERANGGEN DESA TANGKAS & N & $\checkmark \mathbb{N}$ & & $202017-06-07$ & $15: 22: 54$ & $0000-00-00$ & $00: 00: 00$ & I & 1 \\
\hline 4448 & 5105031807072549 & DUSUN MERANGGEN DESA TANGKAS & N & - $\mathbb{N}$ & & $242017-06-07$ & $15: 22: 54$ & $0000-00-00$ & $00: 00: 00$ & I & 1 \\
\hline 4459 & 5105031807072484 & DUSUN PEKEN DESA TANGKAS & N & - & & $302017-06-07$ & $15: 22: 54$ & $0000-00-00$ & $00: 00: 00$ & I & 1 \\
\hline 446368 & 5105031807072438 & DUSUN TUSAN DESA TANGKAS & N & N & & $152017-06-07$ & $15: 24: 36$ & $2017-06-07$ & $15: 54: 29$ & I & 0 \\
\hline 448368 & 5105031807072438 & DUSUN AMBENGAN DESA TANGKAS & Y & $\checkmark Y$ & & $152017-06-07$ & $15: 54: 29$ & $2017-06-07$ & $16: 21: 20$ & u & 0 \\
\hline 449368 & 5105031807072438 & DUSUN AMBENGAN DESA TANGKAS & Y & $\rightarrow Y$ & & $152017-06-07$ & $16: 21: 20$ & $2017-06-07$ & $16: 21: 20$ & D & 0 \\
\hline
\end{tabular}

Gambar 20. Hasil Proses Delete Auditing Untuk Tabel Keluarga

\begin{tabular}{|c|c|c|c|c|c|c|c|c|}
\hline ldi & id_penduduk nik & nama & tempat_1.. & tanggal_lahir & pendapatan_per_bulan time_begin & time_end & st_code & flag \\
\hline 1372 & 15105030710700001 & I WAYAN NADRASH & TAMGKas & $1970-10-07 \quad 00: 00: 00$ & 3000000 2017-06-07 15:22:54 & $0000-00-00 \quad 00: 00: 00$ & & \\
\hline 1373 & 55105030107600004 & I WAYAN TIKA SH & KLUNGKUNG & $1960-12-1200: 00: 00$ & $12000002017-06-07 \quad 15: 22: 54$ & $0000-00-0000: 00: 00$ & I & 1 \\
\hline 1374 & 75105032004880001 & I GEDE JUSTIKA KORI & KLUNGKONG & $1988-04-20 \quad 00: 00: 00$ & $15000002017-06-07 \quad 15: 22: 54$ & $0000-00-0000: 00: 00$ & I & 1 \\
\hline 1375 & 85105030610910001 & I MADE DWIJA PARAMARTHA KORI & KLUNGKUNG & $1991-10-0600: 00: 00$ & $15000002017-06-07 \quad 15: 22: 54$ & $0000-00-00 \quad 00: 00: 00$ & I & 1 \\
\hline 1376 & 95105030107380060 & I KETUI WANDRIS & Tangkas & $1938-12-31 \quad 00: 00: 00$ & $20000002017-06-07 \quad 15: 22: 54$ & $0000-00-0000: 00: 00$ & I & 1 \\
\hline 1377 & 105105034107380087 & NI WAYAII ASIH & TAMGKAS & $1938-12-31 \quad 00: 00: 00$ & $5000002017-06-07 \quad 15: 22: 54$ & $0000-00-00 \quad 00: 00: 00$ & I & 1 \\
\hline 1378 & 115115133112400089 & I NENGAH KAYON & TaMGKas & $1940-12-31 \quad 00: 00: 00$ & $25000002017-06-07 \quad 15: 22: 55$ & $0000-00-00 \quad 00: 00: 00$ & I & 1 \\
\hline 1379 & 135105033112470074 & I NENGAH IISTA & TaMGKas & $1947-12-31 \quad 00: 00: 00$ & $15000002017-06-07 \quad 15: 22: 55$ & $0000-00-0000: 00: 00$ & I & 1 \\
\hline 1380 & 145105037112510098 & NI WAYAN PURNI & GELGEI & $1970-01-01 \quad 00: 00: 00$ & $13000002017-06-07 \quad 15: 22: 55$ & $0000-00-00 \quad 00: 00: 00$ & I & 1 \\
\hline 1381 & 155105033112720022 & I KETUT SUCANA & TaMGKas & $1972-12-31 \quad 00: 00: 00$ & $17000002017-06-07 \quad 15: 22: 55$ & $0000-00-00 \quad 00: 00: 00$ & I & 1 \\
\hline 1382 & 13405105033112728742 & I MADE BELAYO & TAMGKAS & $1988-06-14 \quad 00: 00: 00$ & $20000002017-06-07 \quad 15: 27: 04$ & $2017-06-07 \quad 16: 06: 33$ & I & 0 \\
\hline 1383 & 13405105033112728742 & I MADE BELAYU & TANGKAS & $1988-06-14 \quad 00: 00: 00$ & $30000002017-06-07 \quad 16: 06: 33$ & $2017-06-07 \quad 16: 22: 18$ & u & 0 \\
\hline 1384 & 13405105033112728742 & I MADE BELAYU & IANGKAS & $1988-06-14 \quad 00: 00: 00$ & $3000000 \quad 2017-06-07 \quad 16: 22: 18$ & $2017-06-07 \quad 16: 22: 18$ & D & 0 \\
\hline
\end{tabular}

Gambar 21. Hasil Proses Delete Auditing Untuk Tabel Penduduk

Gambar 20. dan Gambar 21. menunjukkan data hasil delete pada tabel keluarga dengan "id_keluarga" = "368" dan pada tabel penduduk dengan "id_penduduk" = "1340", tersimpan secara historis sebagai row baru didalam tabel auditing. Data hasil delete pada tabel eksisting menunjukan bahwa data tersebut telah non-aktif dari rekaman data hasil insert dan update pada proses sebelumnya, yang ditunjukkan dengan field "flag" bernilai "0".

\section{Kesimpulan}

Berdasarkan penelitian database auditing yang telah di uji coba diatas, dapat disimpulkan bahwa tabel auditing seharusnya dipisahkan dari tabel operasional. Hal ini dilakukan dengan tujuan untuk memisahkan beban kerja analisa dari beban kerja transaksi. Mesin DBMS (Database Management System) dapat menjalankan query auditing lebih cepat ketika tabel auditing terpisah dari tabel operasional daripada menjalankan auditing terhadap satu tabel besar yang tergabung didalam sistem operasional. Selain itu, DBA (Database Administrator) dapat mengelola DBMS menjadi lebih mudah. Memilih desain yang tepat akan mencegah terjadinya penurunan kinerja mesin database, mengurangi redundansi data, menghemat penyimpanan, dan menyederhanakan query auditing. Hasil dari auditing dapat dipelihara untuk keperluan analisis tentang pola akses dan modifikasi terhadap suatu data pada database oleh DBA. 


\section{Daftar Pustaka}

[1] W. Wisswani, "Penerapan Hybrid Slowly Change Dimension Untuk Nearly Realtime Data Warehouse," Lontar Komput., vol. 4, no. 1, 2013.

[2] S. A, M. Sukarsa, and W. B, "Pembentukan Data Mart Menggunakan Metode Generalization," Lontar Komput., vol. 7, no. 3, 2016.

[3] N. Waraporn, "Database Auditing Design on Historical Data," Proc. Second Int. Symp. Netw. Netw. Secur., 2010.

[4] W. Lu and G. Miklau, "Auditing a Database Under Retention Restrictions," IEEE Int. Conf. Data Eng., 2009.

[5] C. Mullins, "Database Auditing Capabilities for Compliance and Security," The Data Administration Newsletter, 2008. [Online]. Available: http://tdan.com/database-auditingcapabilities-for-compliance-and-security/8135.

[6] R. Gudakesa, M. Sukarsa, and A. Sasmita, "Two-Ways Database Synchronization In Homogeneous DBMS Using Audit Log Approach," J. Theor. Appl. Inf. Technol., vol. 65, no. 3, 2014.

[7] L. Yang, "Teaching Database Security and Auditing," Proc. 40th ACM Tech. Sympo-sium Comput. Sci. Educ., 2009.

[8] M. C. Muray, "Database Security: What Students Need to Know," J. Inf. Technol. Educ. Innov. Pract., 2010.

[9] H. Surya, "Rancang Bangun Aplikasi Sinkronisasi Database Dua Arah Pada DBMS Homogen Dengan Pendekatan Binary Log," Universitas Udayana, 2014.

[10] M. C. Mazilu, "Database Replication," Database Sist. J., vol. 1, no. 2, 2010. 